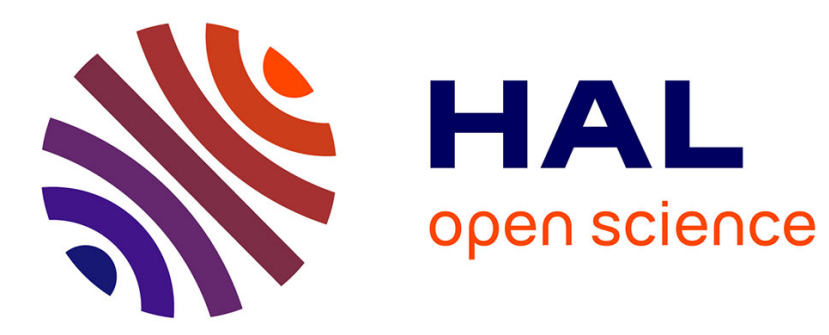

\title{
Androgen receptor and androgen-dependent gene expression in lung
}

Laura Mikkonen, Päivi Pihlajamaa, Biswajyoti Sahu, Fu-Ping Zhang, Olli A. Jänne

\section{- To cite this version:}

Laura Mikkonen, Päivi Pihlajamaa, Biswajyoti Sahu, Fu-Ping Zhang, Olli A. Jänne. Androgen receptor and androgen-dependent gene expression in lung. Molecular and Cellular Endocrinology, 2010, 317 (1-2), pp.14. 10.1016/j.mce.2009.12.022 . hal-00559595

\section{HAL Id: hal-00559595 https://hal.science/hal-00559595}

Submitted on 26 Jan 2011

HAL is a multi-disciplinary open access archive for the deposit and dissemination of scientific research documents, whether they are published or not. The documents may come from teaching and research institutions in France or abroad, or from public or private research centers.
L'archive ouverte pluridisciplinaire HAL, est destinée au dépôt et à la diffusion de documents scientifiques de niveau recherche, publiés ou non, émanant des établissements d'enseignement et de recherche français ou étrangers, des laboratoires publics ou privés. 


\section{Accepted Manuscript}

Title: Androgen receptor and androgen-dependent gene expression in lung

Authors: Laura Mikkonen, Päivi Pihlajamaa, Biswajyoti Sahu, Fu-Ping Zhang, Olli A. Jänne

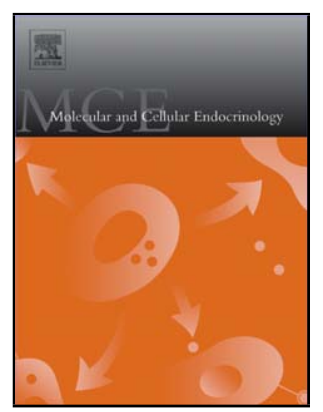

PII:

S0303-7207(09)00653-4

DOI: doi:10.1016/j.mce.2009.12.022

Reference: MCE 7403

To appear in: $\quad$ Molecular and Cellular Endocrinology

Received date: $\quad 9-5-2009$

Revised date: $\quad 16-12-2009$

Accepted date: $\quad$ 16-12-2009

Please cite this article as: Mikkonen, L., Pihlajamaa, P., Sahu, B., Zhang, F.-P., Jänne, O.A., Androgen receptor and androgen-dependent gene expression in lung, Molecular and Cellular Endocrinology (2008), doi:10.1016/j.mce.2009.12.022

This is a PDF file of an unedited manuscript that has been accepted for publication. As a service to our customers we are providing this early version of the manuscript. The manuscript will undergo copyediting, typesetting, and review of the resulting proof before it is published in its final form. Please note that during the production process errors may be discovered which could affect the content, and all legal disclaimers that apply to the journal pertain. 


\title{
Androgen receptor and androgen-dependent gene expression in lung
}

\section{Laura Mikkonen ${ }^{1}$, Päivi Pihlajamaa ${ }^{1}$, Biswajyoti Sahu ${ }^{1}$, Fu-Ping Zhang ${ }^{1}$, and Olli A. Jänne ${ }^{1,2}$}

${ }^{1}$ Biomedicum Helsinki, Institute of Biomedicine (Physiology), University of Helsinki, FI00014 Helsinki, Finland and ${ }^{2}$ Department of Clinical Chemistry, Helsinki University Central Hospital, FI-00290 Helsinki, Finland

Running title: Androgen action in lung

Key words: pneumocyte; gene expression; gene ontology; transcription; glucocorticoid receptor

Address for correspondence

Dr. Olli A. Jänne, M.D., Ph.D.

Biomedicum Helsinki, Institute of Biomedicine

University of Helsinki

Haartmaninkatu 8

FI-00014 Helsinki

Finland

E-mail: olli.janne@helsinki.fi

Phone: +358-9-19125040

\begin{abstract}
Abbreviations used: AR, androgen receptor; ARE, androgen response element; ChIP, chromatin immunoprecipitation; Dex, dexamethasone; FBS, fetal bovine serum; GO, gene ontology; GR, glucocorticoid receptor; PTI and PTII, type I and type II pneumocytes, respectively; $\mathrm{T}$, testosterone
\end{abstract}




\begin{abstract}
The androgen receptor (AR) mediates the effects of male sex steroids. There are major sex differences in lung development and pathologies, including lung cancer. In this report, we show that $A r$ is mainly expressed in type II pneumocytes and the bronchial epithelium of murine lung and that androgen treatment increases AR protein levels in lung cells. Androgen administration altered significantly murine lung gene expression profiles; for example, by up-regulating transcripts involved in oxygen transport and down-regulating those in DNA repair and DNA recombination. Androgen exposure also affected the gene expression profile in a human lung adenocarcinoma-derived cell line, A549, by up- or downregulating significantly some 200 transcripts, including down-regulation of genes involved in cell respiration. Dexamethasone treatment of A549 cells augmented expression of transcript sets that overlapped in part with those up-regulated by androgen in these cells. Moreover, a human lung cancer tissue array revealed that different lung cancer types are all AR-positive. Our results indicate that adult lung is an AR target tissue and suggest that AR plays a role in lung cancer biology.
\end{abstract}




\section{Introduction}

Lung alveoli comprise two epithelial cell types, type I and type II pneumocytes (PTI and PTII, respectively) that enable gaseous exchange. PTI cells form the majority of the epithelium, and while PTII cells account for only about $15 \%$ of peripheral lung cells (Stone et al., 1992), they serve as stem cells that produce new PTI and PTII cells and have other specialized functions. For instance, PTII cells secrete surfactant to reduce the surface tension of the alveoli and decrease the work of breathing by preventing the alveoli from collapsing. Glucocorticoid receptor (GR) is essential in promoting differentiation of PTII cells during embryonic life (Ballard, 1989; Gonzales et al., 2001; Gonzales et al., 2002) and, antenatal glucocorticoid administion expedites lung maturation in infants at risk of preterm delivery (Roberts and Dalziel, 2006), largely through increased surfactant protein expression (Ballard, 1989).

Androgen receptor (AR) mediates the effects of male sex steroids in a variety of reproductive and non-reproductive tissues both in males and females under physiological and pathophysiological conditions (Dehm and Tindall, 2006; Heemers and Tindall, 2007; Heinlein and Chang, 2002; Heinlein and Chang, 2004). Lungs of male fetuses develop more slowly than those of females, and males are more prone to neonatal respiratory distress syndrome due to reduced number of PTII cells and lack of surfactant (Perelman et al., 1986). The AR has been studied in the developing human and murine lungs, and it has been shown to influence branching morphogenesis (Kimura et al., 2003) and to attenuate PTII cell maturation (Dammann et al., 2000; Provost et al., 2000). During development, there are several differentially expressed genes in the lungs of female and male mouse fetuses, including apolipoproteins that may be involved in local lipid metabolism and transport related to surfactant lipid synthesis (Simard et al., 2006). However, the effect of androgens on the gene expression profile in adult lung has not been assessed.

Lung cancer is a disease with a clear sex difference. Female patients show better survival rates than males at any stage of the disease (Fu et al., 2005). Histological subtypes of the disease in women include proportionally more adenocarcinoma and less squamous cell carcinoma than men (Chen et al., 2005; Fu et al., 2005). Overall, men appear to have a higher rate of fatal outcome of lung cancer, but tend to be less vulnerable to tobacco carcinogens than women (International Early Lung Cancer Action Program Investigators et al., 2006). It remains to be elucidated whether these differences result from men 
having lower circulating female sex steroid (estrogen and progesterone) or higher androgen levels than women, or from some as yet unknown confounding associations.

There is a previous report on the presence of $A R$ in adult human lung (Wilson and McPhaul, 1996), but very little is known about functional importance of AR and androgen signaling in lung physiology after embryonal development. To address these issues, we have examined expression of the $A r$ gene and searched for androgen-dependent target genes in adult murine lung. Androgen-treated A549 cells, representing a transformed human PTII adenocarcinoma cell line, were used to compare androgen-dependent gene expression profiles in human cells with those in murine lung. Since androgens and glucocorticoids are known to regulate expression of the same genes, such as the prostate-specific antigen gene (Cleutjens et al., 1977; Thompson et al. 2006), the A549 cells were also employed to examine similarities and differences between gene expression profiles regulated by androgens and glucocorticoids through the AR and GR, respectively.

\section{Materials and methods}

\subsection{Mice and hormone treatments}

Wild-type FVB mice were used. One week after castration, one group of male mice received androgen for five days $[1 \mathrm{mg}$ testosterone $(\mathrm{T}) /$ mouse/day in $0.1 \mathrm{ml}$ of mineral oil as sc injections, corresponding to $30 \mu \mathrm{g} \mathrm{T} / \mathrm{g}$ of body weight], whereas the control group received only vehicle. The dose of the androgen was based on similar previous experiments with mice (Pajunen et al., 1982). Animals were sacrificed on day six, and the lungs were collected for RNA and protein isolation as well as for immunohistochemical analysis. The same hormone treatment ( $30 \mu \mathrm{g} \mathrm{T} / \mathrm{g}$ of body weigth for 5 days) was given in some experiments to intact females. All results originate from a minimum of three biological replicate experiments. All the experiments were performed according to the guidelines for animal experiments at the University of Helsinki and under the license from appropriate Finnish Review Boards for Animal Experiments.

\subsection{Cells}


Lung adenocarcinoma-derived A549 cells were purchased from American Type Culture Collection (Manassas, VA) and maintained in F-12K Nutrient Mixture, Kaighn's Modification (Invitrogen, Carlsbad, CA) with 10\% fetal bovine serum (FBS). This cell line originates from explant culture of lung carcinomatous tissue from a Caucasian male. For hormone exposure experiments, cells were cultured in charcoal-stripped 10\% FBS for $24 \mathrm{~h}$ and then treated either with $100 \mathrm{nM}$ T or $1 \mu \mathrm{M}$ dexamethasone (Dex) in charcoalstripped 2\% FBS for $24 \mathrm{~h}$. The hormone concentrations used were similar to those used by other investigators (So et al., 2007b; Wang et al., 2007). All results are representative of at least two independent experiments.

\subsection{Protein isolation and immunoblotting}

Proteins were isolated from cells or homogenized tissues using a buffer containing $50 \mathrm{mM}$ Tris- $\mathrm{HCl}$ (pH 7.8), $300 \mathrm{mM} \mathrm{NaCl}, 5 \mathrm{mM}$ EDTA, $0.5 \%$ Nonidet P-40, $10 \mathrm{mM} \mathrm{N}$ ethylmaleimide (Sigma-Aldrich, St. Louis, MO), and $1 \mathrm{x}$ complete protease inhibitor set (Roche Diagnostics, Indianapolis, IN). Lysates were centrifuged, and soluble protein concentration was quantified with the BioRad protein assay. Protein samples (50 $\mu \mathrm{g}$ or $30 \mu \mathrm{g})$ were resolved on a 10\% SDS-PAGE gel and transferred onto ECL membrane (GE Healthcare, Buckinghamshire, England). Immunoblotting was performed with rabbit polyclonal IgG against AR (sc-816, Santa Cruz Biotechnology, Inc., Santa Cruz, CA) or rabbit polyclonal IgG against GR (sc-1004, Santa Cruz Biotechnology) or mouse monoclonal $\alpha$ tubulin antibody (sc-5286, Santa Cruz Biotechnology). Horseradish peroxidaseconjugated goat anti-mouse or anti-rabbit IgG was used as secondary antibody. ECL reagent (GE Healthcare) was used for visualization. Band intensities were quantified using the Kodak 1D Scientific Imaging Systems version 3.5.3.

\subsection{Immunohistochemistry}

Lung and prostate tissue samples were fixed immediately after dissection in $4 \%$ paraformaldehyde at $4^{\circ} \mathrm{C}$ overnight, dehydrated and embedded in paraffin. Five- $\mu \mathrm{m}$ sections were mounted onto Superfrost Plus slides (Menzel GmbH, Braunschweig, Germany), dewaxed with xylene, rehydrated and the endogenous peroxidase activity blocked by incubation in $3 \%$ hydrogen peroxide for $15 \mathrm{~min}$. Antigen retrieval was carried out by boil- 
ing the slides in $10 \mathrm{mM}$ sodium citrate ( $\mathrm{pH}$ 6.0). The slides were subsequently blocked with $1 \%$ bovine serum albumin (Sigma-Aldrich) and normal goat serum (Vector Laboratories, Burlingame, CA), and incubated with antibodies against AR (1:1 000 dilution, sc816, Santa Cruz Biotechnology), GR (1:2 000 dilution, sc-1004, Santa Cruz Biotechnology) or hemoglobin $\beta / \gamma / \delta$ (1:100 dilution, sc-21006, Santa Cruz Biotechnology) overnight at $4^{\circ} \mathrm{C}$. The slides were then incubated with biotinylated anti-rabbit IgG secondary antibody as a 1:200 dilution (Vector Laboratories). Negative controls with normal rabbit IgG (sc-2027, Santa Cruz Biotechnology) and in the absence of the primary antibody were included in each experiment. The immune complexes were visualized using the Vectastain Elite $\mathrm{ABC}$ and $\mathrm{DAB}$ substrate kits (Vector Laboratories). A set of slides were counterstained using Mayer's hemalum solution (Merck, Darmstadt, Germany). The slides were dehydrated and mounted using Permount (Fisher Chemicals, Fair Lawn, NJ).

\subsection{Tissue Array}

A206 (Lung Cancer Tissues) AccuMax Array containing total 84 spots including different types of lung carcinoma was purchased from Petagen (Seoul, Korea). The array was immunostained with anti-AR-antibody (sc-816, Santa Cruz Biotechnology) as described above. Another polyclonal AR antibody raised against full-length human receptor (AR3, Thompson et al., 2006) was used to confirm the results.

\subsection{RNA isolation and blotting}

Total RNA was isolated from cells or homogenized tissues using TRIzol reagent (Invitrogen) or Nucleospin RNA II kit (Macherey-Nagel GmbH, Düren, Germany) according to the manufacturers' instructions. Ten $\mu \mathrm{g}$ of total RNA from different mouse tissues were resolved on a $1.2 \%$ denaturing agarose gel and transferred onto a Hybond XL nylon membrane (GE Healthcare). The blot was hybridized with a ${ }^{32} \mathrm{P}$-labeled anti-sense RNA probe corresponding to nucleotides 1301-1655 of Ar cDNA (NM_013476), generated by using Riboprobe Synthesis II kit (Promega, Madison, WI). Hybridization was carried out at $68^{\circ} \mathrm{C}$ in Ultrahyb buffer (Ambion, Austin, TX) overnight. The membrane was washed in $2 \times$ SSC, $0.1 \%$ SDS and $0.1 \times$ SSC, $0.1 \%$ SDS and exposed to Fuji X-ray film at $-70^{\circ} \mathrm{C}$. 


\subsection{Microarray analysis}

The quality of RNA was assessed by Agilent 2100 Bioanalyzer (Agilent, Santa Clara, CA) prior to being subjected to microarray experiments, and the RNA integrity number was $>8$ for each sample. Five $\mu \mathrm{g}$ of total RNA samples from lungs of T-treated castrated male mice $(n=3)$, vehicle-treated castrated male mice $(n=3)$, intact male mice $(n=3)$, intact female mice $(n=3)$, non-treated A549 cells $(n=2)$, T-treated A549 cells $(n=2)$ or Dex-treated A549 cells $(n=2)$ were amplified and labeled to produce cRNA using the Low RNA Input Linear Amp Kit PLUS, Two-Color (Agilent). cRNA was hybridized onto G4122F Whole Mouse Genome chips or G4112F Whole Human Genome chips (Agilent) comprising over 40000 mouse or human genes and transcripts, respectively, according to the manufacturer's instructions. The chips were scanned with Agilent DNA microarray scanner and Feature Extraction Software using Linear and Lowess normalizations. Each chip compared the relative abundance of the transcripts (i.e., abundance differences in the sample pairs) in either T- and vehicle-treated lungs (G4122F chips), intact male and female lungs (G4122F chips), T- and vehicle-treated A549 cells (G4112F chips) or Dexand vehicle-treated A549 cells (G4112F chips).

Microarray results were analyzed with Genespring GX 7.3.1 (Agilent). Data were normalized per spot and per chip as recommended by the manufacturer, and spots flagged as absent in more than half of the samples were removed. Transcripts with fold-change $>1.8$ and Student's t-test p-value $<0.05$ were considered significantly differentially expressed. Genes that were reported by several spots have been kept separate and may appear more than once in the lists. Moreover, the transcripts that did not have a current annotation were removed from the final lists. The resulting lists were analyzed further with Webgestalt (http://bioinfo.vanderbilt.edu/webgestalt) by organizing the lists into Gene Ontology $(\mathrm{GO})$ categories and comparing the categories with those expected by random selection from the whole genome. Original microarray data sets are available at

www.ebi.ac.uk with accession numbers E-MEXP-2001, E-MEXP-2002, E-MEXP-2003, and E-MEXP-2004.

\subsection{Quantitative reverse transcription PCR ( $q R T-P C R)$}


cDNA was synthesized from $3 \mu \mathrm{g}$ of total lung RNA samples using random hexamer primers and Superscript III First-Strand Synthesis System (Invitrogen) according to the manufacturer's instructions. qRT-PCR was performed with LightCycler® 480 RealTime PCR System (Roche Diagnostics) in 20- $\mu$ l reactions containing LightCycler® 480 SYBR Green I Master (Roche Diagnostics) and $1 \mu \mathrm{M}$ forward and reverse primers (see Supplemental data, Table S1). PCR reactions included a 5-min denaturation step $95^{\circ} \mathrm{C}$ followed by 40 cycles of 10 -s denaturation at $95^{\circ} \mathrm{C}, 5$-s annealing at $57-60^{\circ} \mathrm{C}, 20$-s extension at $72^{\circ} \mathrm{C}$ and 5-s SYBR Green signal measurement. Melting curve analysis was performed for each product to detect possible non-specific products. The results were analyzed with LightCycler analysis software (Roche Diagnostics). The results were normalized to glyceraldehyde-3-phosphate dehydrogenase (GAPDH) mRNA levels.

\subsection{Chromatin immunoprecipitation}

Chromatin immunoprecipitation (ChIP) was performed essentially as previously described (Kang et al., 2004; Thompson et al., 2006). Briefly, $10^{6}$ A549 cells were seeded on 10-cm dishes and maintained for 4 days in 10\% charcoal-stripped FBS, F-12K Nutrient Mixture medium. The cells were exposed to either $100 \mathrm{nM}$ T or vehicle for $16 \mathrm{~h}$ and then cross-linked in $1 \%$ formaldehyde. The cells were harvested into lysis buffer and pelleted by centrifugation. Chromatin was sonicated to an average DNA length of 500-800 nt. Sonicated samples were precleared with normal rabbit IgG and GammaBind G Sepharose (GE Healthcare) and immunoprecipitated with AR antiserum (sc-816, Santa Cruz Biotechnology). Antibody-bound complexes were adsorbed to GammaBind G Sepharose beads that were sequentially washed with TSE I, TSE II, TSE III, and TE buffers (Kang et al., 2004). DNA was eluted from the matrix with $1 \%$ SDS in $0.1 \mathrm{M} \mathrm{NaHCO}_{3}$, crosslinking was reverted at $65^{\circ} \mathrm{C}$ overnight, and DNA isolated using QIAquick PCR purification system (Qiagen GmbH, Hilden, Germany). Input samples were treated the same way except that no immunoprecipitation was performed. qRT-PCR was performed with LightCycler 480 System in $20-\mu 1$ reactions containing LightCycler 480 SYBR Green I Master and $1 \mu \mathrm{M}$ forward and reverse primers for the genomic regions examined (Supplemental data, Table S1). PCR reactions included a 5-min denaturation step at $95^{\circ} \mathrm{C}$, followed by 40 cycles of 10 -s denaturation at $95^{\circ} \mathrm{C}, 5$-s annealing at $60^{\circ} \mathrm{C}, 5$-s extension at 
$72^{\circ} \mathrm{C}$ and 5-s SYBR Green signal measurement. The immunoprecipitated samples were normalized to input values.

\section{Results}

\subsection{Lung cell expression of the Ar gene}

Ar mRNA was detected in hybridization blots of total murine lung RNA as a distinct $\sim 10-\mathrm{kb}$ band. The presence of Ar mRNA size heterogeneity has been reported previously (Tilley et al., 1990; Shan et al., 1990), with two mRNA species of $\sim 10 \mathrm{~kb}$ and $\sim 8$ $\mathrm{kb}$ in size. This latter $A r$ mRNA species was barely detectable in murine lung but corresponded to the principal $A r$ mRNA from in brain (Fig. 1A). The abundance of $A r$ mRNA in lung was comparable to that in brain, but less than in kidney or prostate. This result was confirmed with RT-PCR (data not shown). Five-day T treatment increased AR protein levels in lungs of both castrated males and intact females, as revealed by immunoblotting of tissue extracts (Fig. 1B), and the amount of AR in the castrated male lung appeared to be higher than that in female lung. Likewise, lung AR protein level was lower in castrated than in intact male mice (Figs. 1C, 1D). Up-regulation of AR levels either by physiological or pharmacological amounts of androgen is likely to be due to ligand-dependent stabilization of $\mathrm{AR}$, as has been found in other AR-containing tissues or cells (Shan et al., 1990; Kemppainen et al., 1992; Zhou et al., 1995; Mora et al., 1996). In support to this notion, five-day $\mathrm{T}$ treatment failed to alter significantly $A r$ mRNA levels in murine lung (results not shown). As reported previously (Wollmer et al., 1996), we detected AR protein in a human cancer cell line derived from PTII cells (the A549 cell line), and upon androgen exposure, A549 cell AR protein level was increased in a fashion similar to that in murine lung (Fig. 1E).

AR antigen was detected by immunohistochemistry in nuclei of murine PTII and bronchial epithelial cells of intact male mice (Fig. 2A). In these experiments, a murine prostate sample served as a positive control, and showed clear staining of the epithelial cell nuclei (Supplemental Fig. S1). In comparison, GR immunoreactivity exhibited a more universal distribution than that of AR in the same tissue sections, and all lung cell types expressed GR antigen (Fig. 2B). Upon androgen treatment of castrated male mice, AR immunostaining of the lung became more intense, but the subcellular localization of AR 
antigen did not change significantly (Figs. 2C and 2D), whereas the intensity of GR immunostaining was independent of androgen exposure (data not shown).

\subsection{Androgen treatment affects gene expression profile in murine lung}

In search of androgen-regulated genes in murine lung, we performed gene expression profiling using the Agilent Whole Mouse Genome platform. By using the cut-off values of fold-change $>1.8$ and $p$ value $<0.05$, we identified 46 up-regulated and 134 downregulated transcripts in lung of castrated male mice after $\mathrm{T}$ treatment (Supplemental data, Table S2). To infer the biological processes potentially regulated by androgens, the genes were grouped into gene ontology (GO) categories. These categories were compared with the expected ones by using the Webgestalt mouse as a reference gene set, and the hypergeometric test was used to calculate the $\mathrm{p}$ values. Among the enriched categories in the up-regulated genes were those involved in oxygen transport ( 4 genes, $\mathrm{p}=3.59 \mathrm{e}-8$ ), negative regulation of apoptosis ( 3 genes, $\mathrm{p}=3.79 \mathrm{e}-3$ ), hemopoiesis ( 3 genes, $\mathrm{p}=8.02 \mathrm{e}-3$ ) and heme biosynthesis ( 2 genes, $\mathrm{p}=2.14 \mathrm{e}-4)$. The down-regulated genes belonged to categories such as DNA repair (5 genes, $\mathrm{p}=6.65 \mathrm{e}-3$ ), DNA recombination (3 genes, $\mathrm{p}=9.19 \mathrm{e}-3$ ), and double-strand break repair (2 genes $\mathrm{p}=4.20 \mathrm{e}-3$ ) (Table 1). Quantitative RT-PCR was used to confirm expression levels of a few selected transcripts, and all transcript levels quantified by qPCR were in good agreement with the microarray results (Table 2).

To examine sexual dimorphism in lung gene expression and to search for genes potentially regulated by physiological androgen concentrations, gene expression profiling was performed on male and female lungs. With the same cut-off values as above (foldchange $>1.8$ and $\mathrm{p}$ value $<0.05$ ), we identified 28 up-regulated and 99 down-regulated transcripts in male lungs as compared to female lungs (Supplemental data, Table S3). Some of the up-regulated genes in males belonged to muscle development (3 genes, $\mathrm{p}=2.28 \mathrm{e}-4)$ and muscle contraction ( 6 genes, $\mathrm{p}=3.78 \mathrm{e}-11)$. The down-regulated genes included genes involved in acute inflammatory response ( 3 genes, $\mathrm{p}=6.05 \mathrm{e}-3)$ and regulation of translation ( 2 genes, $\mathrm{p}=4.58 \mathrm{e}-2$ ) (Table 3). As could have been expected, Y chromosome-encoded transcripts were highly overrepresented in the male samples. These included genes such as Eif2s3y,Ddx3y and Uty. Xist, the $\mathrm{X}$ inactive specific transcript in females, was at the top of the list of down-regulated genes in males. 
The gene lists covering the two data sets - T-treated lungs vs. non-treated lungs of castrated male mice, and intact male $v s$. intact female lungs - exhibited very limited overlap. There were 7 overlapping down-regulated transcripts that included 6 genes: Kcnj8, Txk, DOH4S114, Hsd17b12, BC002199, and Tmem46. The up-regulated lists did not overlap when the cut-off was set at fold change of 1.8. However, when the cut-off value was relaxed to fold change of 1.5, the lists of up-regulated genes overlapped by 9 transcripts ( 7 genes: Myl7, Hrc, Tnnt2, Mb, Fgll, Cdh2 and Junb).

Gene expression profiling experiments revealed androgen-dependent up-regulation of several hemoglobin-related transcripts (Hbb-bl, Hbb-y, Hbq1,Mb) in the murine lung. To examine whether up-regulation was due to increased expression of these genes by lung cells or increased blood cell retention in lung as a consequence of $\mathrm{T}$ administration, we performed immunohistochemical analyses with an antibody recognizing several hemoglobin variants $(\beta, \gamma$ and $\delta)$ on murine lung tissue sections. This antibody stained primarily the nuclei of all lung cell types, and T treatment appeared to bring about an increase in signal intensity within these cells (Fig. 2E and F).

\subsection{AR is present in normal and malignant human lung cells}

Lung carcinoma tumors and normal adjacent tissue showed AR immunoreactivity in normal lung, and all lung cancer types within the array included at least a few samples that were clearly AR-positive (Fig. 3). AR staining was mainly nuclear, although diffuse cytoplasmic staining was also present in many samples. The tissue array comprised samples from adenocarcinoma (7 AR-positive of 15 samples), squamous cell carcinoma (11/15), bronchioloalveolar carcinoma (2/3), large cell neuroendocrine carcinoma (2/2), large cell carcinoma (2/3), and small cell carcinoma (2/2). The staining of the tumor was not dependent on the sex of the patient. All normal lung tissue specimens in the array exhibited clear AR immunoreactivity, but the signal intensity varied among the samples. An other AR antibody (Thompson et al., 2006) was used to confirm the immunostaining results.

\subsection{Androgen exposure affects gene expression of A549 cells}


To study the effects of $\mathrm{T}$ on cultured human lung cancer cells, we profiled gene expression in A549 cells with or without T treatment. Androgen exposure for $24 \mathrm{~h}$ resulted in up-regulation of 126 transcripts, but only 62 of these were annotated as transcripts encoded by known genes (Supplemental data, Table S4). Of the known AR target genes, the list included TMPRSS2 and EPB41L4B (Bolton et al., 2007; Wang et al., 2007). The genes belonged to the following GO categories: phospholipid metabolism ( 2 genes, $\mathrm{p}=0.03$ ), iron ion binding ( 3 genes, $\mathrm{p}=0.046$ ), oxygen binding ( 2 genes, $\mathrm{p}=0.0057$ ), heme binding ( 3 genes, $\mathrm{p}=0.0028$ ) and clathrin-coated vesicle ( 2 genes, $\mathrm{p}=0.03$ ) (Supplemental data, Table S5). T elicited down-regulation of 111 transcripts, 98 of which corresponded to currently known genes (Supplemental data, Table S4), and these included the following GO categories: cellular respiration ( 3 genes, $\mathrm{p}=0.0006$ ), metabolism (44 genes, $\mathrm{p}=0.009$ ), mitochondrion ( 8 genes, $\mathrm{p}=0.008$ ) and clathrin coat of trans-Golgi network vesicle (3 genes, $\mathrm{p}=0.00004)$. Among the enriched categories of down-regulated genes was also regulation of apoptosis ( 6 genes, $\mathrm{p}=0.008$ ); these genes included both negative regulation ( 3 genes, $\mathrm{p}=0.02$ ) and positive regulation of apoptosis ( 4 genes, $\mathrm{p}=0.009$ ) (Supplemental data, Table S5). Unlike mouse lung in vivo, expression of hemoglobin genes was not significant up-regulated by androgen in A549 cells. This result may relate to the fact that expression levels of all hemoglobin genes were extremely low in A549 cells.

AR regulates gene expression through canonical androgen response elements (AREs) and non-canonical AREs (Wang et al., 2007), and class I nuclear receptors, such as $\mathrm{AR}, \mathrm{GR}$, progesterone receptor, and mineralocorticoid receptor, may recognize the same canonical response elements (for a review, see Verrijdt et al., 2003). It was, therefore, of interest to expose A549 cells to Dex and compare AR and GR target genes in the context of a single cell line. As expected, more A549 transcripts were regulated by Dex than $\mathrm{T}$ exposure. Likewise, Dex responses were more robust than those with $\mathrm{T}$. With the cut-off value of 2-fold change, Dex up-regulated the abundance of 1510 transcripts (compared to 74 with $\mathrm{T}$ at the same fold change), and 1285 transcripts were down-regulated by Dex (compared to 56 with T). Nevertheless, there was some overlap in transcript regulation, in that 40 transcripts were common for $\mathrm{T}$ and Dex among the up-regulated genes, whereas only 11 common ones were among the down-regulated genes (Fig. 4). Among the most Dex-responsive genes [>3-fold up-regulation (510 transcripts corresponding to 416 known genes); Supplemental data, Table S6] were those involved in lipid metabolism (23 genes, $\mathrm{p}=9.8 \mathrm{e}-5$ ), suggesting a possible increase in surfactant production (Supplemental 
data, Table S7). A few of the surfactant-related genes were up-regulated in Dex-treated cells, such as SFTPD (10.4-fold), SFTPG (3.7-fold), and PGC (12.2-fold). Some other genes encoding surfactant-associated proteins were expressed at very low abundance and were, therefore, flagged in the analysis as being absent. Genes down-regulated by Dex (225 transcripts, 209 known genes) included those in stress response (15 genes, $\mathrm{p}=7 \mathrm{e}-3$ ), DNA metabolism (19 genes, $\mathrm{p}=5 \mathrm{e}-5)$, and mitosis (12 genes, $\mathrm{p}=8 \mathrm{e}-8$ ) (Supplemental data, Table S7).

The transcripts that were up-regulated at least 2-fold by both $\mathrm{T}$ and Dex included several interesting genes that are listed in Table 4. One of the genes listed in this table, TMPRSS2, is known to harbor an androgen-responsive enhancer at $\sim 14 \mathrm{~kb}$ of transcription start site (Wang et al., 2007). The TMPRSS2 locus plays also an important role in prostate cancer biology, as it is a common place for translocation of genes encoding members of the ETS transcription factor family (Tomlins et al., 2005). In view of this, it was of interest to observe that, in A549 cells, there was androgen-dependent loading of AR onto the TMPRSS2 enhancer, as revealed by ChIP assays (Fig. 5). There is no other information on potential AR-binding sites in the regulatory regions of androgen-regulated genes in A549 cells. However, our ongoing experiments on LNCaP-1F5 prostate cancer cell line have employed ChIP with AR antibody followed by ultrahigh-throughput parallel sequencing (ChIP-seq) to delineate genome-wide AR-binding sites on chromatin (our unpublished observations). Even though this AR-binding site information originates from a different cell line, it was still pertinent to examine their occurrence in androgen-regulated genes of the A549 cells. We found that $39 \%$ of androgen up-regulated and 36\% of down-regulated genes contained putative AR-dinding sites within $200 \mathrm{~kb}$ of transcription start sites. On the basis of this analysis, additional ChIP assays were performed on two other loci, an ARbinding site at $21 \mathrm{~kb}$ upstream of the TAS2R50 gene encoding a G-protein coupled taste receptor and a negative control site at $57 \mathrm{~kb}$ down-stream of the PDGFRA gene. Upon androgen exposure for $16 \mathrm{~h}$, there was significantly increased loading of AR on the former but not onto the latter site (Fig. 5). Up-regulation of TMPRSS2 and TAS2R50 mRNA levels upon T treatment was confirmed by qPCR (Supplemental data, Table S3). 


\section{Discussion}

\subsection{Localization of AR expression to specific lung cell types}

In addition to fetal lung (Dammann et al., 2000; Kimura et al., 2003; Provost et al., 2004), we have now shown that adult lung is an androgen-responsive tissue in both mice and humans, and the AR is expressed predominantly in the bronchial epithelium and PTII cells. The latter cells are important in the maintenance of alveolar epithelium by (i) providing new epithelial cells and (ii) secreting surfactant. Since T delays maturation of PTII cells during embryonic development (Provost et al., 2004), it is not surprising that $A r$ is also expressed in these cells in adult mice. In view of the specific role of PTII cells in surfactant production, AR might also influence surfactant biosynthesis, but there are no reports to indicate that androgen insensitive $T \mathrm{fm} / \mathrm{Y}$ mice or human androgen insensitive patients have a lung phenotype. Moreover, although lung surfactant composition of $T \mathrm{fm} / Y$ mice differs from that of wild-type mice during development (Nielsen, 1985), we failed to observe significant androgen-dependent differences in transcripts encoding surfactant proteins in adult lung, between either T-treated and castrated male mice or intact male and female mice.

\subsection{Androgen-regulated gene expression in mouse lung and A549 cells}

Androgen-dependent genes in the murine lung include those in iron binding and oxygen transport and, in particular, many hemoglobin-related gene transcripts. Hemoglobin genes are expressed, not only in blood cells, but also in cultured PTII and Clara cells (Newton et al., 2006), and cellular hemoglobin is proposed to serve as a protective agent against oxidative and nitrosative stress (Liu et al., 2000; Minning et al., 1999). Androgen treatment not only increased expression of genes involved in oxygen transport, such as those encoding hemoglobins, but it also decreased expression of genes involved in DNA damage repair. It is tempting to speculate that cells with increased protection against oxidative stress would require less DNA repair proteins. Case-control studies have shown that women have an increased risk of lung cancer over that in men with the same consumption of tobacco (Risch et al., 1993; Zang and Wynder, 1996). Interestingly, one of the genes that was most down-regulated in male vs. female murine lung was Cyplal that encodes an 
enzyme involved in metabolism of polycyclic aromatic hydrocarbons. Increased expression of this enzyme in women has been proposed to play a role in their elevated lung cancer risk (Mollerup et al., 1999).

Several androgen-regulated genes did not respond in lung in the same ways as in some other androgen target tissues. Tissue-specific differences are not surprising, since gene expression depends on chromatin modifications, coactivators and corepressors typical of a given cellular environment. For example, $\operatorname{Ig} f l$ was significantly down-regulated in lung, whereas it is up-regulated in other androgen target tissues (Bolton et al., 2007). In addition, Angptl4, a gene that is linked to lung cancer metastasis seeding via the TGF- $\beta$ signaling pathway (Padua et al., 2008), is down-regulated by androgen in prostate cancer cells (Bolton et al., 2007) but up-regulated in murine lung. Up-regulation of the ANGPTL4 gene has also been linked to hypoxic conditions in human fetal cardiac cells and neonatal rat cardiomyocytes (Belanger et al., 2002). This, together with up-regulated hemoglobin genes, could relate to the ways by which the lung reacts to changing oxygen levels. Another interesting gene that was one of the most androgen down-regulated genes in murine lung is D0H4S114, also known as P311, which has a role in distal lung morphogenesis during development, and its absence in adults may result in emphysema (Zhao et al., 2006).

Many genes that were androgen-regulated in A549 cells are known AR targets in other tissues. These genes include TMPRSS2 (up-regulated by androgens in prostate cancer, Tomlins et al., 2005; Wang et al., 2007) and EPB41L4B (Bolton et al., 2007). Similar to mouse lung, the list of up-regulated genes in A549 cells included significant enrichment of GO categories dealing with oxygen binding, heme binding and iron ion binding, even though the genes whose expression was modulated by androgens were not the same. Collectively, our results imply that androgens play a role in transport and utilization of oxygen in lung.

Although the enriched GO categories showed similarity between murine lung and human A549 lung cancer cells, differentially expressed single genes were not the same. However, A549 cells represent a malignant human cell line and may not reflect all functions of intact PTII cells. In addition, PTII cells are not the only lung cells expressing AR. As the lung tissue represents the first-line defense between the body and its surroundings, environmental conditions ought to play a more significant role in modulating gene expres- 
sion in vivo than in cultured cells. Therefore, an intact organism (murine lung) is likely to express different gene sets than cells (A549 cells) under culture conditions.

\subsection{Comparison of $T$ and Dex regulation of A549 cell gene expression profiles}

Glucocorticoid receptor $(\mathrm{Gr})$ null mice die during the first few hours after birth due to respiratory failure (Cole et al., 1995), and GR protein is expressed in all cell types of the lung. To examine a potential overlap between androgen- and glucocorticoiddependent genes in lung cells, we compared gene expression profiles of A549 cells exposed to either T or Dex. Most of the genes identified previously by chromatin immuno-

precipitation-microarray (ChIP-on-chip) studies in Dex-treated A549 cells (So et al., 2007a) were included in our list of differentially expressed ( $>2$-fold) genes in Dex-treated cells. The majority of genes regulated by T or Dex in A549 cells were distinct, indicating that AR possesses functions that are independent of GR signaling in lung cells. Nevertheless, gene expression profiles from T- and Dex-treated A549 cells also showed the presence of overlapping sets of transcripts, and it is therefore likely that some of the androgenresponsive genes are also regulated by GR signaling. Interestingly, the majority of these genes were up-regulated by both $\mathrm{T}$ and Dex. Whether or not this is due to binding of ligand-occupied AR and GR to the same genomic elements remains to be elucidated.

\subsection{AR and lung cancer}

There are several reports implicating the estrogen signaling pathway in lung cancer (Marquez-Garban et al., 2007), and clear sex differences exist in lung cancer type and survival (Belani et al., 2007; Chen et al., 2005; Fu et al., 2005; Patel, 2005; Thomas et al., 2005). In particular, women who do not smoke are more susceptible to developing adenocarcinoma, a cancer type that derives from PTII cells expressing AR. Since epidermal growth factor receptor (EGFR) plays a major role in adenocarcinoma (Johnson and Jänne, 2005), it is interesting that an inhibitor of EGFR which is widely used to treat lung adenocarcinoma, gefitinib, has been shown to lower androgen levels especially in patients responding to treatment (Nishio et al., 2005). Our results show that some human lung cancers express AR, and a human alveolar carcinoma-derived cell line with PTII-like properties, A549, not only contains AR but also exhibits androgen-dependent gene expression. Some 
of the androgen-responsive genes in these cells belong to interesting categories with regard to survival of malignant cells, such as oxygen utilization and apoptosis. This result combined to androgen-responsive genes in murine lung, involving iron ion binding, DNA repair and angiogenesis, makes the role of androgens in lung cancer biology worthy of further inquiry. In this regard, TMPRSS 2 was one of the genes that was up-regulated upon androgen exposure and a direct AR target in A549 cells, as judged by ChIP experiments. This gene is also an AR target in prostate (Wang et al., 2007), and a locus for translocation of ETS transcription factors in about $50 \%$ of prostate cancers (Kumar-Sinha et al., 2008; Tomlins et al., 2005). It is currently not known whether a similar translocation takes place in a subset of lung cancers. With regard to lung cancer development and metastasis seeding, it was of particular interest to find androgen-dependent up-regulation of Angptl4 in murine lung, as this TGF- $\beta$ regulated gene has been implicated in lung cancer progression and metastatic potential (Padua et al., 2008). This gene is also a PPAR $\gamma$ target (Yoon et al., 2000), and PPAR $\gamma$ agonists reduce the growth of non-small cell lung cancer derived cells - including adenocarcinoma (Chang and Szabo, 2000) - in vitro, and patients with diabetes using PPAR $\gamma$ agonists have a reduced risk of lung cancer (Govindarajan et al., 2007). In conclusion, our data suggest that AR, along with other nuclear receptors, plays a role in lung cancer biology.

\section{Acknowledgments}

We thank Saija Kotola, Johanna Iso-Oja and Anne Reijula for excellent technical assistance, Massimiliano Gentile for helping with the microarray analysis and Ismo Virtanen for helping with histological techniques. This work was supported by grants from the Academy of Finland, Biocentrum Helsinki, Sigrid Jusélius Foundation, Finnish Foundation for Cancer Research, Paulo Foundation, Oskar Öflund Foundation, Emil Aaltonen Foundation, Finnish Medical Foundation, Helsinki University Central Hospital, and European Union (CASCADE). 


\section{References}

Ballard, P.L., 1989. Hormonal regulation of pulmonary surfactant. Endocr. Rev. 10, 165181.

Belanger, A.J., Lu, H., Date, T., Liu, L.X., Vincent, K.A., Akita, G.Y., Cheng, S.H., Gregory, R.J., Jiang, C., 2002. Hypoxia up-regulates expression of peroxisome proliferatoractivated receptor gamma angiopoietin-related gene (pgar) in cardiomyocytes: role of hypoxia inducible factor $1 \alpha$. J. Mol. Cell. Cardiol. 34, 765-774.

Belani, C.P., Marts, S., Schiller, J., Socinski, M.A., 2007. Women and lung cancer: epidemiology, tumor biology, and emerging trends in clinical research. Lung Cancer 55, 1523.

Bolton, E.C., So, A.Y., Chaivorapol, C., Haqq, C.M., Li, H., Yamamoto, K.R., 2007. Celland gene-specific regulation of primary target genes by the androgen receptor. Genes. Dev. 21, 2005-2017.

Chang, T.H., Szabo, E., 2000. Induction of differentiation and apoptosis by ligands of peroxisome proliferator-activated receptor gamma in non-small cell lung cancer. Cancer Res. 60, 1129-1138.

Chen, K.Y., Chang, C.H., Yu, C.J., Kuo, S.H., Yang, P.C., 2005. Distribution according to histologic type and outcome by gender and age group in Taiwanese patients with lung carcinoma. Cancer 103, 2566-2574.

Cleutjens, C.B., Steketee, K., van Eekelen, C.C., van der Korput, J.A., Brinkmann, A.O. Trapman, J., 1997. Both androgen receptor and glucocorticoid receptor are able to induce prostate-specific antigen expression, but differ in their growth-stimulating properties of LNCaP cells. Endocrinology 138, 5293-5300.

Cole, T.J., Blendy, J.A., Monaghan, A.P., Krieglstein, K., Schmid, W., Aguzzi, A., Fantuzzi, G., Hummler, E., Unsicker, K., Schütz, G., 1995. Targeted disruption of the gluco- 
corticoid receptor gene blocks adrenergic chromaffin cell development and severely retards lung maturation. Genes. Dev. 9, 1608-1621.

Dammann, C.E., Ramadurai, S.M., McCants, D.D., Pham, L.D., Nielsen, H.C., 2000. Androgen regulation of signaling pathways in late fetal mouse lung development. Endocrinology 141, 2923-2929.

Dehm, S.M., Tindall, D.J., 2006. Molecular regulation of androgen action in prostate cancer. J. Cell. Biochem. 99, 333-344.

Fu, J.B., Kau, T.Y., Severson, R.K., Kalemkerian, G.P., 2005. Lung cancer in women: analysis of the national surveillance, epidemiology, and end results database. Chest 127, $768-777$.

Gonzales, L.W., Angampalli, S., Guttentag, S.H., Beers, M.F., Feinstein, S.I., Matlapudi, A., Ballard, P.L., 2001. Maintenance of differentiated function of the surfactant system in human fetal lung type II epithelial cells cultured on plastic. Pediatr. Pathol. Mol. Med. 20, $387-412$

Gonzales, L.W., Guttentag, S.H., Wade, K.C., Postle, A.D., Ballard, P.L., 2002. Differentiation of human pulmonary type II cells in vitro by glucocorticoid plus cAMP. Am. J. Physiol. Lung. Cell. Mol. Physiol. 283, L940-L951.

Govindarajan, R., Ratnasinghe, L., Simmons, D.L., Siegel, E.R., Midathada, M.V., Kim, L., Kim, P.J., Owens, R.J., Lang, N.P., 2007. Thiazolidinediones and the risk of lung, prostate, and colon cancer in patients with diabetes. J. Clin. Oncol. 25, 1476-1481.

Heemers, H.V., Tindall, D.J., 2007. Androgen receptor (AR) coregulators: a diversity of functions converging on and regulating the AR transcriptional complex. Endocr. Rev. 28, 778-808.

Heinlein, C.A., Chang, C., 2002. Androgen receptor (AR) coregulators: an overview. Endocr. Rev. 23, 175-200. 
Heinlein, C.A., Chang, C., 2004. Androgen receptor in prostate cancer. Endocr. Rev. 25, 276-308.

International Early Lung Cancer Action Program Investigators, Henschke, C.I., Yip, R., Miettinen, O.S., 2006. Women's susceptibility to tobacco carcinogens and survival after diagnosis of lung cancer. JAMA 296, 180-184.

Johnson, B.E., Jänne, P.A., 2005. Epidermal growth factor receptor mutations in patients with non-small cell lung cancer. Cancer Res. 65, 7525-7529.

Kang, Z., Jänne, O.A., Palvimo, J.J., 2004. Coregulator recruitment and histone modifications in transcriptional regulation by the androgen receptor. Mol. Endocrinol. 18, 26332648.

Kemppainen, J.A., Lane, M.V., Sar, M., Wilson, E.M., 1992. Androgen receptor phosphorylation, turnover, nuclear transport, and transcriptional activation. Specificity for steroids and antihormones. J. Biol. Chem. 267, 968-974.

Kimura, Y., Suzuki, T., Kaneko, C., Darnel, A.D., Akahira, J., Ebina, M., Nukiwa, T., Sa-

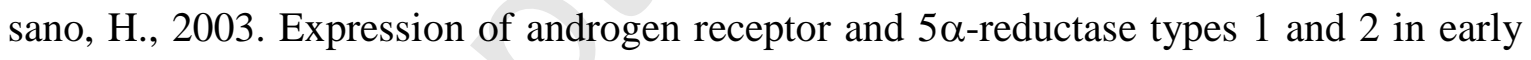
gestation fetal lung: a possible correlation with branching morphogenesis. Clin. Sci. (Lond). 105, 709-713.

Kumar-Sinha, C., Tomlins, S.A., Chinnaiyan, A.M., 2008. Recurrent gene fusions in prostate cancer. Nat. Rev. Cancer 8, 497-511.

Liu, L., Zeng, M., Hausladen, A., Heitman, J., Stamler, J.S., 2000. Protection from nitrosative stress by yeast flavohemoglobin. Proc. Natl. Acad. Sci. U.S.A. 97, 4672-4676.

Marquez-Garban, D.C., Chen, H.W., Fishbein, M.C., Goodglick, L., Pietras, R.J., 2007. Estrogen receptor signaling pathways in human non-small cell lung cancer. Steroids 72, $135-143$. 
Minning, D.M., Gow, A.J., Bonaventura, J., Braun, R., Dewhirst, M., Goldberg, D.E., Stamler, J.S., 1999. Ascaris haemoglobin is a nitric oxide-activated 'deoxygenase'. Nature 401, 497-502.

Mollerup, S., Ryberg, D., Hewer, A., Phillips, D.H., Haugen, A., 1999. Sex differences in lung CYP1A1 expression and DNA adduct levels among lung cancer patients. Cancer Res. 59, 3317-3320.

Mora, G.R., Prins, G.S., Mahesh, V.B., 1996. Autoregulation of androgen receptor protein and messenger RNA in rat ventral prostate is protein synthesis dependent. J. Steroid. Biochem. Mol. Biol. 58, 539-549.

Newton, D.A., Rao, K.M., Dluhy, R.A., Baatz, J.E., 2006. Hemoglobin is expressed by alveolar epithelial cells. J. Biol. Chem. 281, 5668-5676.

Nielsen, H.C., 1985. Androgen receptors influence the production of pulmonary surfactant in the testicular feminization mouse fetus. J. Clin. Invest. 76, 177-181.

Nishio, M., Ohyanagi, F., Horiike, A., Ishikawa, Y., Satoh, Y., Okumura, S., Nakagawa, K., Nishio, K., Horai, T., 2005. Gefitinib treatment affects androgen levels in non-smallcell lung cancer patients. Br. J. Cancer 92, 1877-1880.

Padua, D., Zhang, X.H., Wang, Q., Nadal, C., Gerald, W.L., Gomis, R.R., Massagué, J., 2008. TGF $\beta$ primes breast tumors for lung metastasis seeding through angiopoietin-like 4. Cell 133, 66-77.

Pajunen, A.E.I., Isomaa, V.V., Jänne, O.A., Bardin, C.W., 1982. Androgenic regulation of ornithine decarboxylase activity in mouse kidney and its relationship to changes in cytosol and nuclear androgen receptor concentrations. J. Biol. Chem. 257, 8190-8198.

Patel, J.D., 2005. Lung cancer in women. J. Clin. Oncol. 23, 3212-3218. 
Perelman, R.H., Palta, M., Kirby, R., Farrell, P.M., 1986. Discordance between male and female deaths due to the respiratory distress syndrome. Pediatrics 78, 238-244.

Provost, P.R., Blomquist, C.H., Godin, C., Huang, X.F., Flamand, N., Luu-The, V., Nadeau, D., Tremblay, Y., 2000. Androgen formation and metabolism in the pulmonary epithelial cell line A549: expression of 17 $\beta$-hydroxysteroid dehydrogenase type 5 and $3 \alpha-$ hydroxysteroid dehydrogenase type 3. Endocrinology 141, 2786-2794.

Provost, P.R., Simard, M., Tremblay, Y., 2004. A link between lung androgen metabolism and the emergence of mature epithelial type II cells. Am. J. Respir. Crit. Care Med. 170, 296-305.

Risch, H.A., Howe, G.R., Jain, M., Burch, J.D., Holowaty, E.J., Miller, A.B., 1993. Are female smokers at higher risk for lung cancer than male smokers? A case-control analysis by histologic type. Am. J. Epidemiol. 138, 281-293.

Roberts, D., Dalziel, S., 2006. Antenatal corticosteroids for accelerating fetal lung maturation for women at risk of preterm birth. Cochrane Database Syst. Rev. 3, CD004454.

Shan, L-X., Rodriguez, M.C., Jänne, O.A., 1990. Regulation of androgen receptor protein and messenger RNA concentrations by androgens in rat ventral prostate and seminal vesicles and in human hepatoma cells. Mol. Endocrinol. 4, 1636-1646.

Simard, M., Provost, P.R., Tremblay, Y., 2006. Sexually dimorphic gene expression that overlaps maturation of type II pneumonocytes in fetal mouse lungs. Reprod. Biol. Endocrinol. 4, 25.

So, A.Y., Chaivorapol, C., Bolton, E.C., Li, H., Yamamoto, K.R., 2007a. Determinants of cell- and gene-specific transcriptional regulation by the glucocorticoid receptor. PLoS Genet. 3, e94. 
So, A.Y., Cooper, S.B., Feldman, B.J., Manuchehri, M., Yamamoto, K.R., 2007b. Conservation analysis predicts in vivo occupancy of glucocorticoid receptor-binding sequences at glucocorticoid-induced genes. Proc. Natl. Acad. Sci. U.S.A. 105, 5745-5749.

Stone, K.C., Mercer, R.R., Gehr, P., Stockstill, B., Crapo, J.D., 1992. Allometric relationships of cell numbers and size in the mammalian lung. Am. J. Respir. Cell. Mol. Biol. 6, $235-243$.

Thomas, L., Doyle, L.A., Edelman, M.J., 2005. Lung cancer in women: emerging differences in epidemiology, biology, and therapy. Chest 128, 370-381.

Thompson, J., Lepikhova, T., Teixido-Travesa, N., Whitehead, M., Palvimo, J.J., Jänne, O.A., 2006. Small carboxyl-terminal domain phosphatase 2 attenuates androgendependent transcription. EMBO J. 25, 2757-2767.

Tilley, W.D., Marcelli, M., McPhaul, M.J., 1990. Expression of the human androgen receptor gene utilizes a common promoter in diverse human tissues and cell line. J. Biol. Chem. 265, 13776-13781.

Tomlins, S.A., Rhodes, D.R., Perner, S., Dhanasekaran, S.M., Mehra, R., Sun, X.W., Varambally, S., Cao, X., Tchinda, J., Kuefer, R., Lee, C., Montie, J.E., Shah, R.B., Pienta, K.J., Rubin, M.A., Chinnaiyan, A.M., 2005. Recurrent fusion of TMPRSS2 and ETS transcription factor genes in prostate cancer. Science 310, 644-648.

Verrijdt, G., Haelens, A., Claessens, F., 2003. Selective DNA recognition by the androgen receptor as a mechanism for hormone-specific regulation of gene expression. Mol. Genet. Metab. 78, 175-185.

Wang, Q., Li, W., Liu, X.S., Carroll, J.S., Jänne, O.A., Keeton, E.K., Chinnaiyan, A.M., Pienta, K.J., Brown, M., 2007. A hierarchical network of transcription factors governs androgen receptor-dependent prostate cancer growth. Mol. Cell 27, 380-392. 
Wilson, C.M., McPhaul, M.J., 1996. A and B forms of the androgen receptor are expressed in a variety of human tissues. Mol. Cell. Endocrinol. 120, 51-57.

Wollmer, E., Branscheid, D., Gazdar, A.F., Havemann, K., 1996. Steroid-hormone receptors in cell lines and tumor biopsies of human lung cancer. Int. J. Cancer 67, 357-364.

Yoon, J.C., Chickering, T.W., Rosen, E.D., Dussault, B., Qin, Y., Soukas, A., Friedman, J.M., Holmes, W.E., Spiegelman, B.M., 2000. Peroxisome proliferator-activated receptor gamma target gene encoding a novel angiopoietin-related protein associated with adipose differentiation. Mol. Cell. Biol. 20, 5343-5349.

Zang, E.A., Wynder, E.L., 1996. Differences in lung cancer risk between men and women: examination of the evidence. J. Natl. Cancer Inst. 88, 183-192.

Zhao, L., Leung, J.K., Yamamoto, H., Goswami, S., Kheradmand, F., Vu, T.H., 2006. Identification of P311 as a potential gene regulating alveolar generation. Am. J. Respir. Cell Mol. Biol. 35, 48-54.

Zhou, Z.X., Lane, M.V., Kemppainen, J.A., French, F.S., Wilson, E.M., 1995. Specificity of ligand-dependent androgen receptor stabilization: receptor domain interactions influence ligand dissociation and receptor stability. Mol. Endocrinol. 9, 208-218. 


\section{Figure legends}

Fig. 1. Androgen receptor mRNA and protein expression in the lung. A, Ten $\mu \mathrm{g}$ of total RNA from different mouse tissues were resolved on a $1.2 \%$ formaldehyde denaturing agarose gel, transferred onto a nylon membrane and hybridized with a ${ }^{32} \mathrm{P}$-labeled $A r$ cRNA probe as described in the Materials and Methods. B, Immunoblot analysis of AR protein in murine lung. Female or castrated male mice were treated testosterone $(\mathrm{T})$ for 5 days; control animals received vehicle only. Soluble lung proteins $(50 \mu \mathrm{g})$ were resolved by SDSPAGE gel electrophoresis and immunoblotted using antibodies against AR or GR. C, AR protein levels in the lung of intact and castrated male mice. Soluble protein extracts $(50 \mu \mathrm{g}$ protein) were resolved by SDS-PAGE gel electrophoresis and immunoblotted using antibodies against AR D, A549 cells were treated with $100 \mathrm{nM}$ testosterone (T) for $24 \mathrm{~h}$. Total protein $(50 \mu \mathrm{g})$ extracts were resolved on an SDS-PAGE and immunoblotted with an antibody against AR. $\alpha$-Tubulin was used to control for equal loadings.

Fig. 2. Localization of AR, GR and hemoglobin in lung cells. A and B, Serial lung sections of male mice were immunostained with an antibody against AR (A) or GR (B) to show localization of AR to type II pneumocytes and bronchial epithelium, and the ubiquitous presence of GR. C and D, Influence of androgen treatment on AR localization. Castrated mice were given vehicle (C) or testosterone for 5 days (D). E and F, Influence of androgen treatment on hemoglobin immunostaining. Tissue sections from lungs of castrated $(\mathrm{E})$ or androgen-treated $(\mathrm{F})$ male mice were immunostained with antibody against hemoglobin $\beta / \gamma / \delta$. Panels A and B were counterstained with hematoxylin. Scale bar $=50$ $\mu \mathrm{m}$.

Fig. 3. Immunoreactive AR in lung cancer specimens. Shown are examples of ARpositive sections from a human lung cancer tissue array comprising 80 spots from 40 lung cancer specimens and 4 non-neoplastic spots. The array was immunostained with AR antibody. The pictures show examples of immunoreactive spots from adenocarcinoma (A), squamous cell carcinoma (B), bronchioloalveolar carcinoma (C), small cell carcinoma (D), large cell carcinoma (E), and normal human lung tissue (F). Scale bar $=50 \mu \mathrm{m}$. 
Fig. 4. Comparison of transcript numbers regulated by androgen and glucocorticoid in A549 cells. The cells were treated with $100 \mathrm{nM}$ T, $1 \mu \mathrm{M}$ Dex or vehicle for $24 \mathrm{~h}$. Gene expression profiling was conducted as described in Materials and Methods. The figures show the overlap of the transcripts that were significantly regulated by either $\mathrm{T}$ or Dex.

Fig. 5. Loading of AR onto the TMPRSS2 and TAS2R50 enhancers in A549 cells upon androgen exposure. The cells were exposed to $100 \mathrm{nM} \mathrm{T}$ or vehicle for $16 \mathrm{~h}$. Precleared samples were immunoprecipitated with anti-AR-antibody. qRT-PCR was performed using primers for the TMPRSS2 and TAS2R50 enhancers and the bars represent relative foldchanges (+SEM) for $\mathrm{T}$ treatment in comparison to vehicle-treated samples (C) set at 1.0. PDGFRA refers to a control chromosomal site located at $57 \mathrm{~kb}$ down-stream of the PDGFRA gene. 
Table 1. Enriched gene ontology (GO) categories in murine lung upon $\mathrm{T}$ treatment

Agilent Whole Mouse Genome expression microarray was used to compare gene-expression in lungs of castrated male mice treated with testosterone for five days to those of vehicle-treated animals. The GO categories are shown for transcripts that were differentially expressed (fold-change $>1.8$, t-test $\mathrm{p}$ value $<0.05$ ).

\begin{tabular}{|c|c|c|c|c|c|c|}
\hline \multicolumn{7}{|l|}{ Up-regulated Genes } \\
\hline GO category & p-value (GO) & Gene Symbol & Common Name & Entrez ID & Fold Change & p-value \\
\hline \multirow{4}{*}{ oxygen transport } & $3.59 \mathrm{E}-08$ & Hbb-b1 & hemoglobin, beta adult major chain & 15129 & 3.20 & 0.0276 \\
\hline & & Hbb-y & hemoglobin Y, beta-like embryonic chain & 15135 & 2.00 & 0.0330 \\
\hline & & Hbq1 & hemoglobin, theta 1 & 216635 & 1.86 & 0.0028 \\
\hline & & $\mathrm{Mb}$ & myoglobin & 17189 & 1.86 & 0.0059 \\
\hline \multirow[t]{3}{*}{ negative regulation of apoptosis } & $3.79 \mathrm{E}-03$ & Angpt14 & angiopoietin-like 4 & 57875 & 2.02 & 0.0075 \\
\hline & & $\mathrm{Tsc} 22 \mathrm{~d} 3$ & TSC22 domain family 3 & 14605 & 1.86 & 0.0088 \\
\hline & & Fgf8 & fibroblast growth factor 8 & 14179 & 1.84 & 0.0182 \\
\hline \multirow[t]{7}{*}{ iron ion binding } & 5.93E-06 & Hbb-b1 & hemoglobin, beta adult major chain & 15129 & 3.20 & 0.0276 \\
\hline & & Rsad2 & radical S-adenosyl methionine domain containing 2 & 58185 & 2.40 & 0.0007 \\
\hline & & Fech & ferrochelatase & 14151 & 2.38 & 0.0013 \\
\hline & & Slc25a37 & solute carrier family 25 , member 37 & 67712 & 2.18 & 0.0034 \\
\hline & & Hbb-y & hemoglobin Y, beta-like embryonic chain & 15135 & 2.00 & 0.0330 \\
\hline & & Hbq1 & hemoglobin, theta 1 & 216635 & 1.86 & 0.0028 \\
\hline & & $\mathrm{Mb}$ & myoglobin & 17189 & 1.86 & 0.0059 \\
\hline \multirow[t]{2}{*}{ heme biosynthesis } & 2.14E-04 & Alas2 & aminolevulinic acid synthase 2 , erythroid & 11656 & 2.50 & 0.0023 \\
\hline & & Fech & ferrochelatase & 14151 & 2.38 & 0.0013 \\
\hline \multicolumn{7}{|l|}{ Down-regulated Genes } \\
\hline GO category & p-value (GO) & Gene Symbol & Common Name & Entrez ID & Fold Change & p-value \\
\hline \multirow[t]{3}{*}{ DNA repair } & $6.65 \mathrm{E}-03$ & Brca2 & breast cancer 2 & 12190 & -2.08 & 0.0049 \\
\hline & & H2afx & H2A histone family, member X & 15270 & -1.82 & 0.0219 \\
\hline & & $\operatorname{Rev} 31$ & REV3-like, catalytic subunit of DNA polymerase zeta RAD54 like (S. cerevisiae) & 19714 & -1.81 & 0.0095 \\
\hline \multirow[t]{3}{*}{ DNA recombination } & $9.19 \mathrm{E}-03$ & $\mathrm{Brca} 2$ & breast cancer 2 & 12190 & -2.08 & 0.0049 \\
\hline & & Msh6 & mutS homolog 6 (E. coli) & 17688 & -1.90 & 0.0269 \\
\hline & & H2afx & $\mathrm{H} 2 \mathrm{~A}$ histone family, member $\mathrm{X}$ & 15270 & -1.82 & 0.0219 \\
\hline \multirow[t]{2}{*}{ double-strand break repair } & 4.20E-03 & Brca2 & breast cancer 2 & 12190 & -2.08 & 0.0049 \\
\hline & & H2afx & H2A histone family, member $\mathrm{X}$ & 15270 & -1.82 & 0.0219 \\
\hline \multirow[t]{10}{*}{ response to stress } & $1.73 \mathrm{E}-02$ & Brca2 & breast cancer 2 & 12190 & -2.08 & 0.0049 \\
\hline & & $\mathrm{C} 1 \mathrm{~s}$ & complement component $1, \mathrm{~s}$ subcomponent & 50908 & -2.02 & 0.0044 \\
\hline & & Hsp90ab1 & heat shock protein $90 \mathrm{kDa}$ alpha (cytosolic), class B member 1 & 15516 & -1.90 & 0.0227 \\
\hline & & Msh6 & mutS homolog 6 (E. coli) & 17688 & -1.90 & 0.0269 \\
\hline & & Pold3 & polymerase (DNA-directed), delta 3, accessory subunit & 67967 & -1.90 & 0.0277 \\
\hline & & Fn1 & fibronectin 1 & 14268 & -1.86 & 0.0171 \\
\hline & & Txnip & thioredoxin interacting protein & 56338 & -1.85 & 0.0061 \\
\hline & & Lta4h & leukotriene A4 hydrolase & 16993 & -1.85 & 0.0158 \\
\hline & & H2afx & H2A histone family, member X & 15270 & -1.82 & 0.0219 \\
\hline & & $\operatorname{Rev} 31$ & REV3-like, catalytic subunit of DNA polymerase zeta RAD54 like (S. cerevisiae) & 19714 & -1.81 & 0.0095 \\
\hline
\end{tabular}


Table 2. Enriched gene ontology (GO) categories between intact male and female mouse lung

Agilent Whole Mouse Genome expression microarray was used to compare gene-expression in the lung tissue of intact male and female mice. The GO categories are shown for transcripts that were differentially expressed (fold-change $>1.8$, t-test $\mathrm{p}$ value $<0.05$ ).

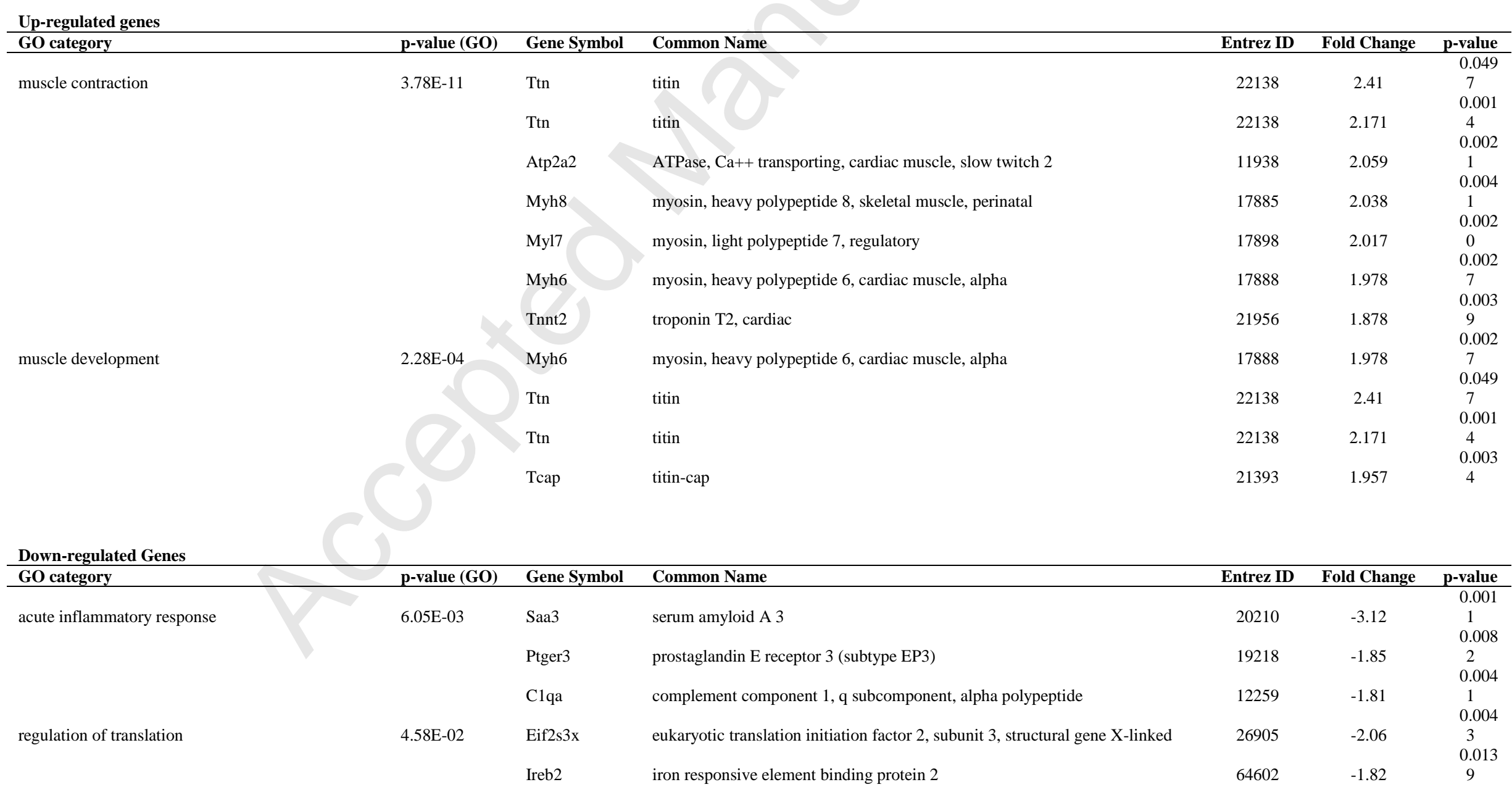


enzyme linked receptor protein signaling pathway

$3.11 \mathrm{E}-02$

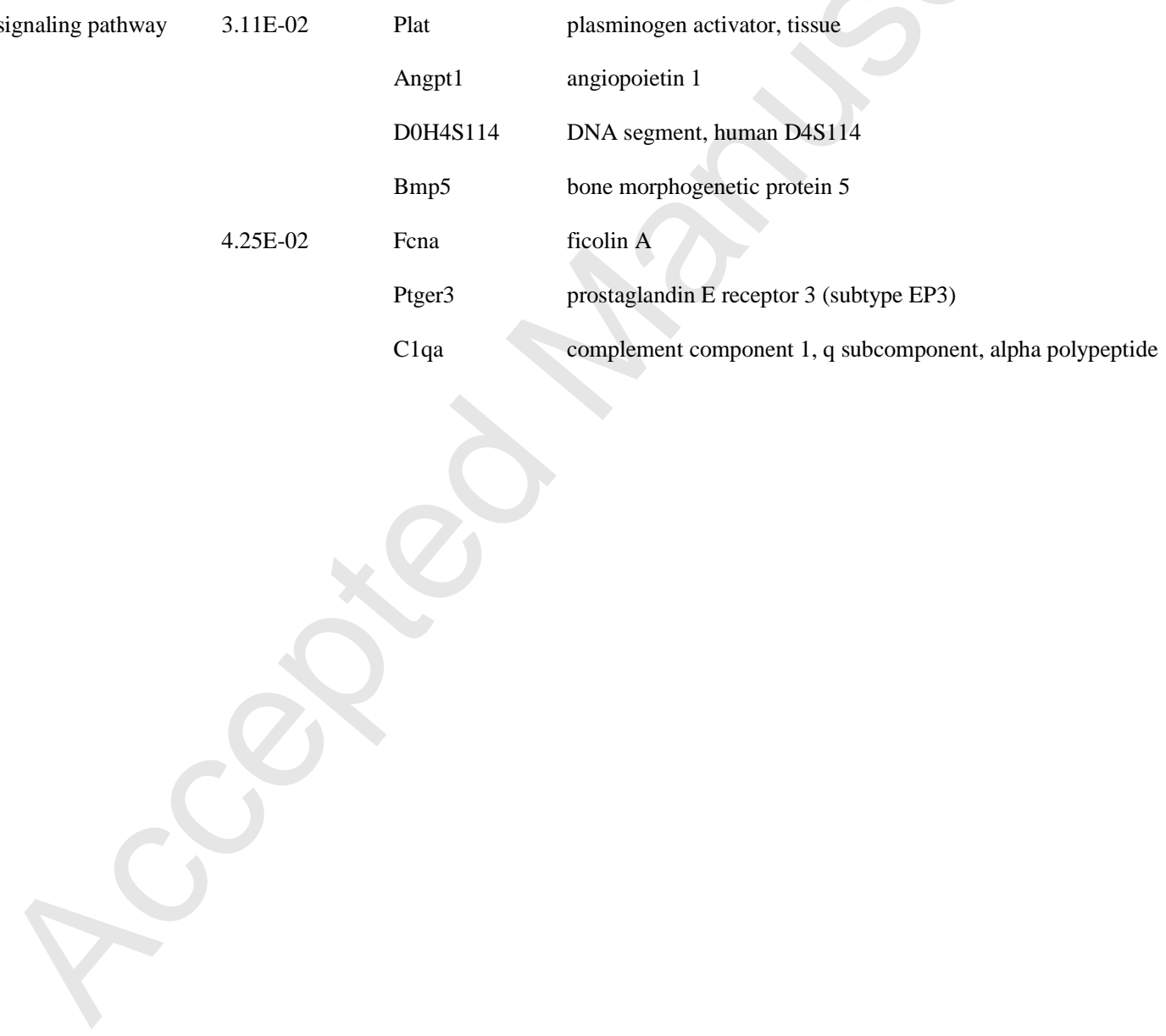

18791

11600

27528

12160

14133

19218

12259
0.004

0.007

3

4

1

3 
Table 3. Genes differentially expressed by both T and Dex in A549 cells

Agilent Whole Human Genome expression microarray was used to compare gene-expression in A549 cells. Genes included in the lists were differentially expressed $>2$-fold compared to vehicle ( $t$-test $\mathrm{p}$-value $<0.05)$.

Up-regulated Genes

\begin{tabular}{l} 
Gene Symbol \\
\hline AQP10 \\
CILP2 \\
CNGB1 \\
CXorf36 \\
CYP1A1 \\
CYP2E1 \\
CYP7A1 \\
DKKL1 \\
DMRTC1 \\
DPCR1 \\
FLJ21438 \\
FOLH1 \\
FOLR2 \\
GIPR \\
GYPC \\
HEMK1 \\
HIF3A \\
KIAA1881 \\
LOC387761 \\
PLA2G3 \\
PPP1R14C \\
PSORS1C2 \\
SEMA6A \\
SERINC2 \\
SPRR2D \\
TAS2R50 \\
TCL1A \\
TMPRSS2 \\
TTC21B
\end{tabular}

Common Name

aquaporin 10

cartilage intermediate layer protein 2

cyclic nucleotide gated channel beta 1

chromosome $\mathrm{X}$ open reading frame 36

cytochrome P450, family 1, subfamily A, polypeptide 1

cytochrome P450, family 2 , subfamily E, polypeptide 1

cytochrome P450, family 7, subfamily A, polypeptide 1

dickkopf-like 1 (soggy)

DMRT-like family C1

diffuse panbronchiolitis critical region 1

hypothetical protein FLJ21438

folate hydrolase (prostate-specific membrane antigen) 1

folate receptor 2 (fetal)

gastric inhibitory polypeptide receptor

glycophorin C (Gerbich blood group) (GYPC)

HemK methyltransferase family member 1

hypoxia inducible factor 3 , alpha subunit

KIAA1881

hypothetical LOC387761

phospholipase A2, group III

protein phosphatase 1, regulatory (inhibitor) subunit $14 \mathrm{C}$

psoriasis susceptibility 1 candidate 2

sema domain, transmembrane domain (TM), and cytoplasmic domain, (semaphorin) 6A

serine incorporator 2

small proline-rich protein $2 \mathrm{D}$

taste receptor, type 2 , member 50

T-cell leukemia/lymphoma $1 \mathrm{~A}$

transmembrane protease, serine 2

tetratricopeptide repeat domain $21 \mathrm{~B}$

\begin{tabular}{c} 
Entrez Gene \\
\hline 89872 \\
148113 \\
1258 \\
79742 \\
1543 \\
1571 \\
1581 \\
27120 \\
63947 \\
135656 \\
64926 \\
2346 \\
2350 \\
2696 \\
2995 \\
51409 \\
64344 \\
114782 \\
387761 \\
50487 \\
81706 \\
170680 \\
57556 \\
347735 \\
6703 \\
259296 \\
8115 \\
7113 \\
79809 \\
\end{tabular}

Down-regulated Genes

\begin{tabular}{llc}
\hline Gown-regulated Genes & & \\
\hline Cene Symbol & Common Name & \\
\hline AK097130 & cDNA FLJ39811 fis, clone SPLEN2009581 \\
FLJ20464 & cDNA FLJ20464 fis, clone KAT06158 & Entrez Gene \\
GINS4 & GINS complex subunit 4 (Sld5 homolog) & 54944 \\
GRLF1 & glucocorticoid receptor DNA binding factor 1 & 84296 \\
IGSF11 & immunoglobulin superfamily, member 11 & 2909 \\
PNMA6A & paraneoplastic antigen like 6A & 152404 \\
SMOC1 & SPARC related modular calcium binding 1 & 84968 \\
TMEM142B & transmembrane protein 142B & 64093 \\
UBXN7 & UBX domain protein 7
\end{tabular}


A
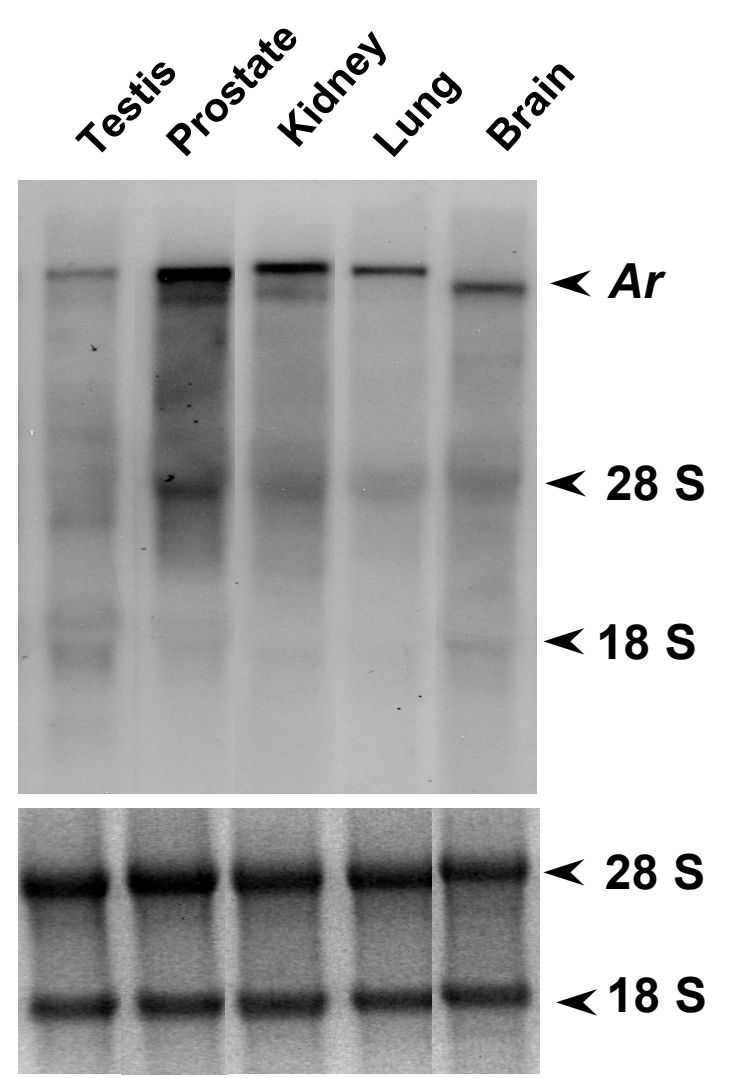

D

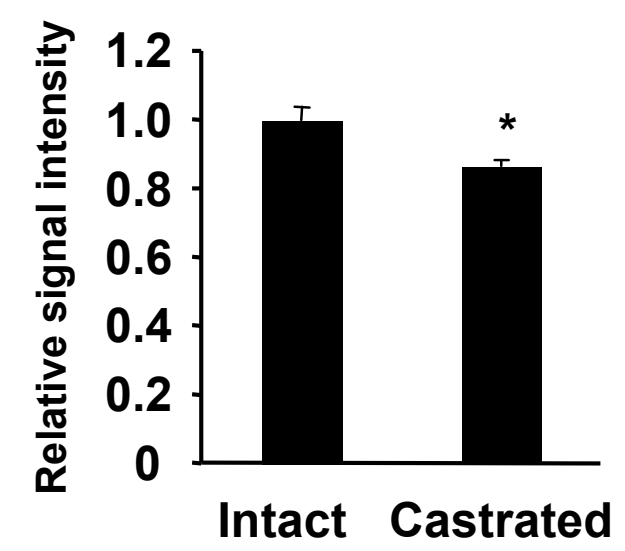

B
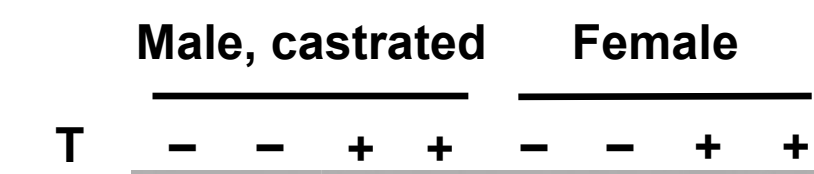

AR >

GR >

tub >

C

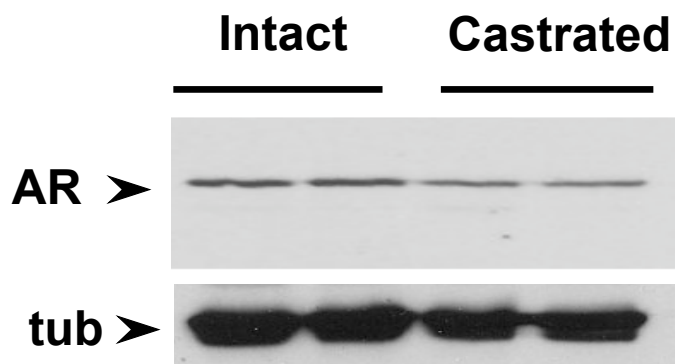

E

Vehicle

100 nM T, 24 h

tub >

Fig. 1 
Fig. 2
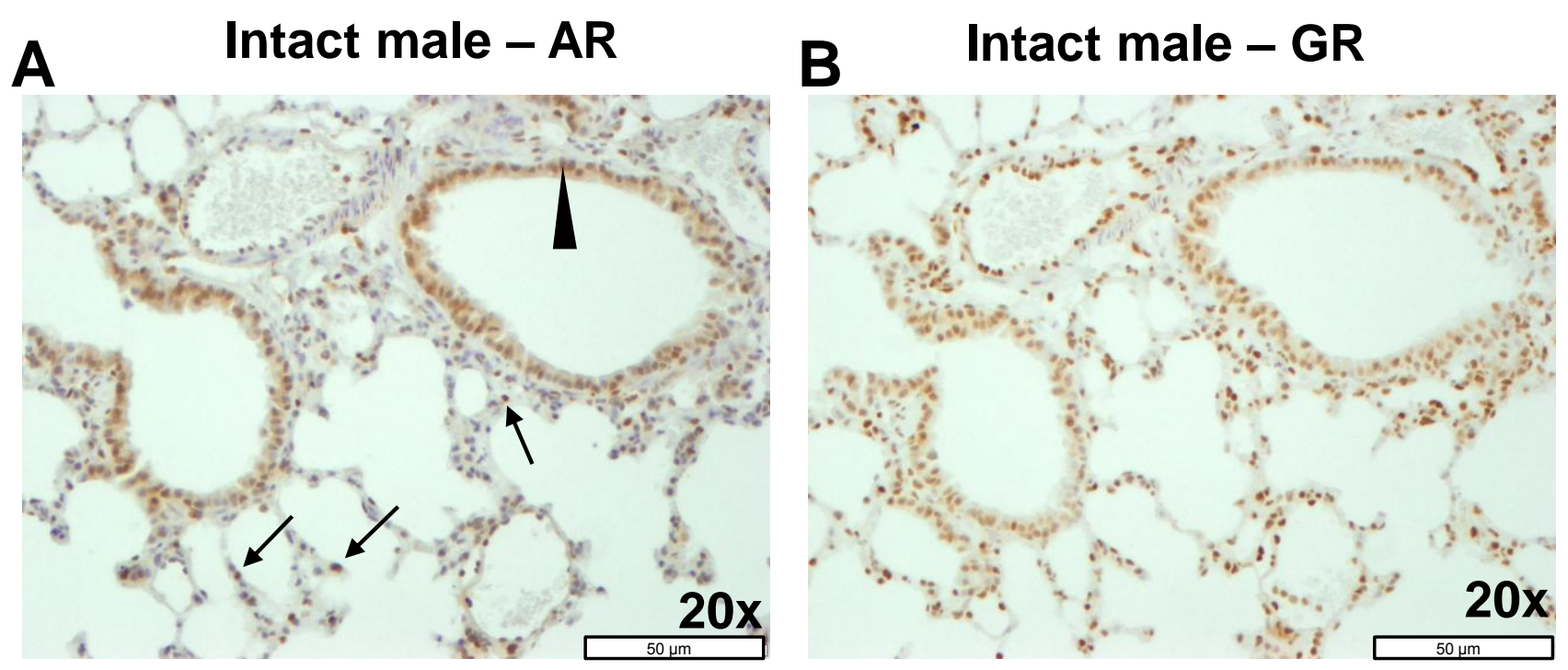

\section{Castrated male - AR}

\section{Castrated male + T - AR}
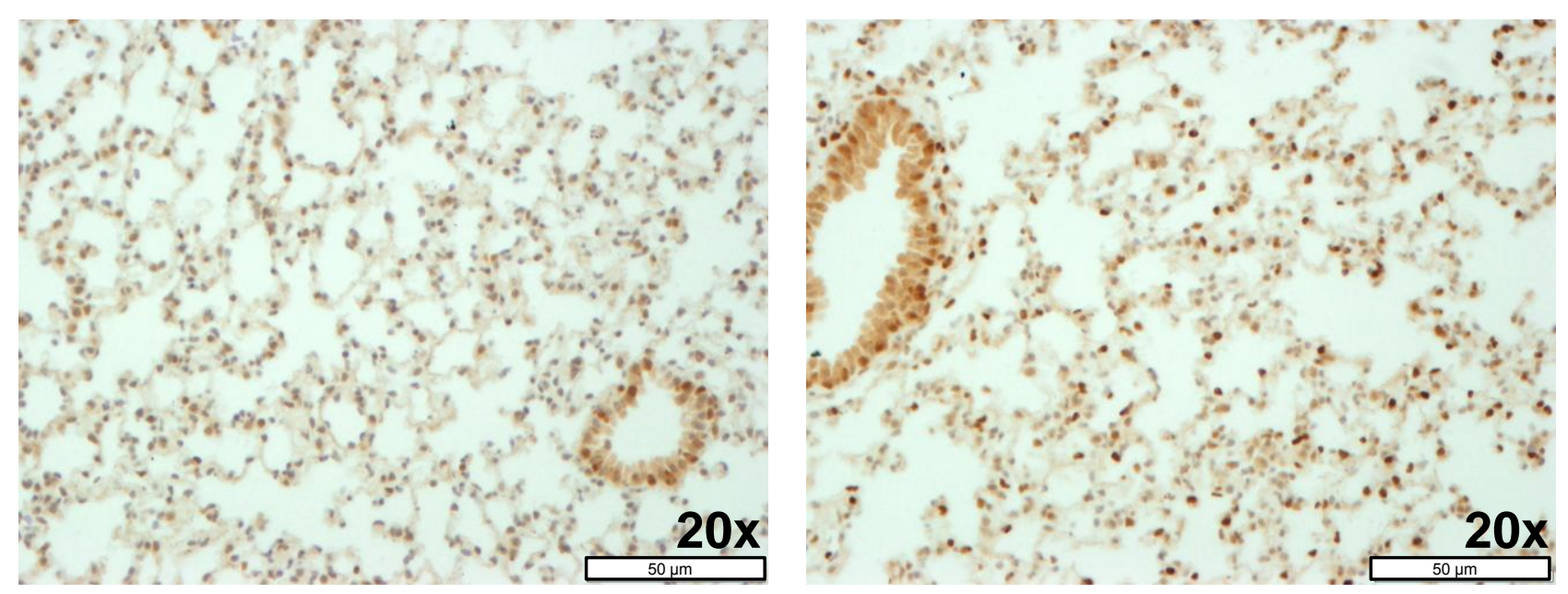

\section{E Castrated male - $\mathrm{Hb}$}


Fig. 3

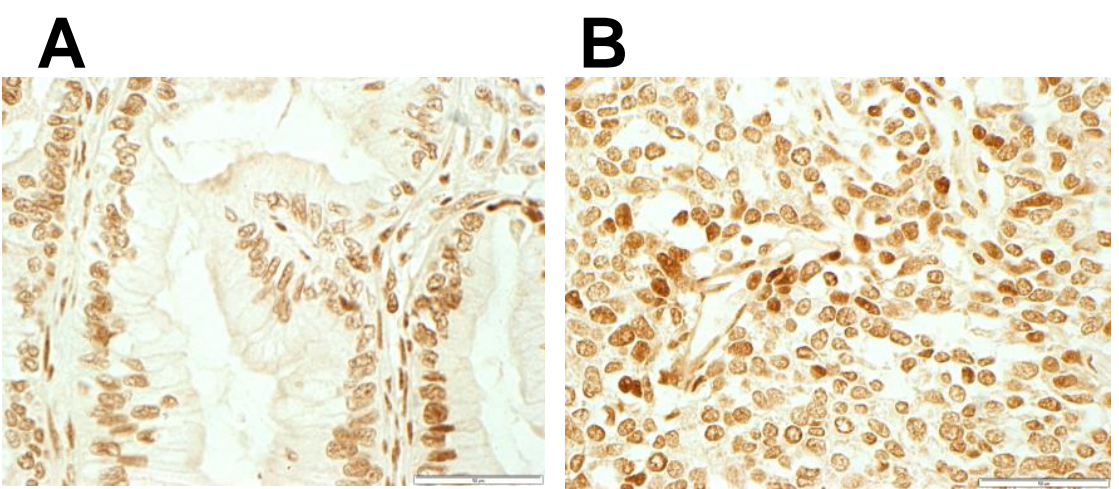

\section{C}

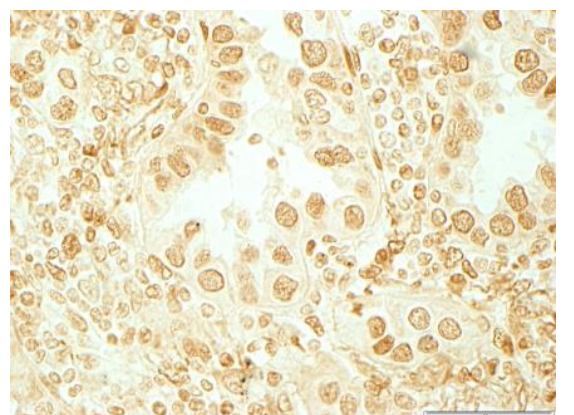

\section{D}
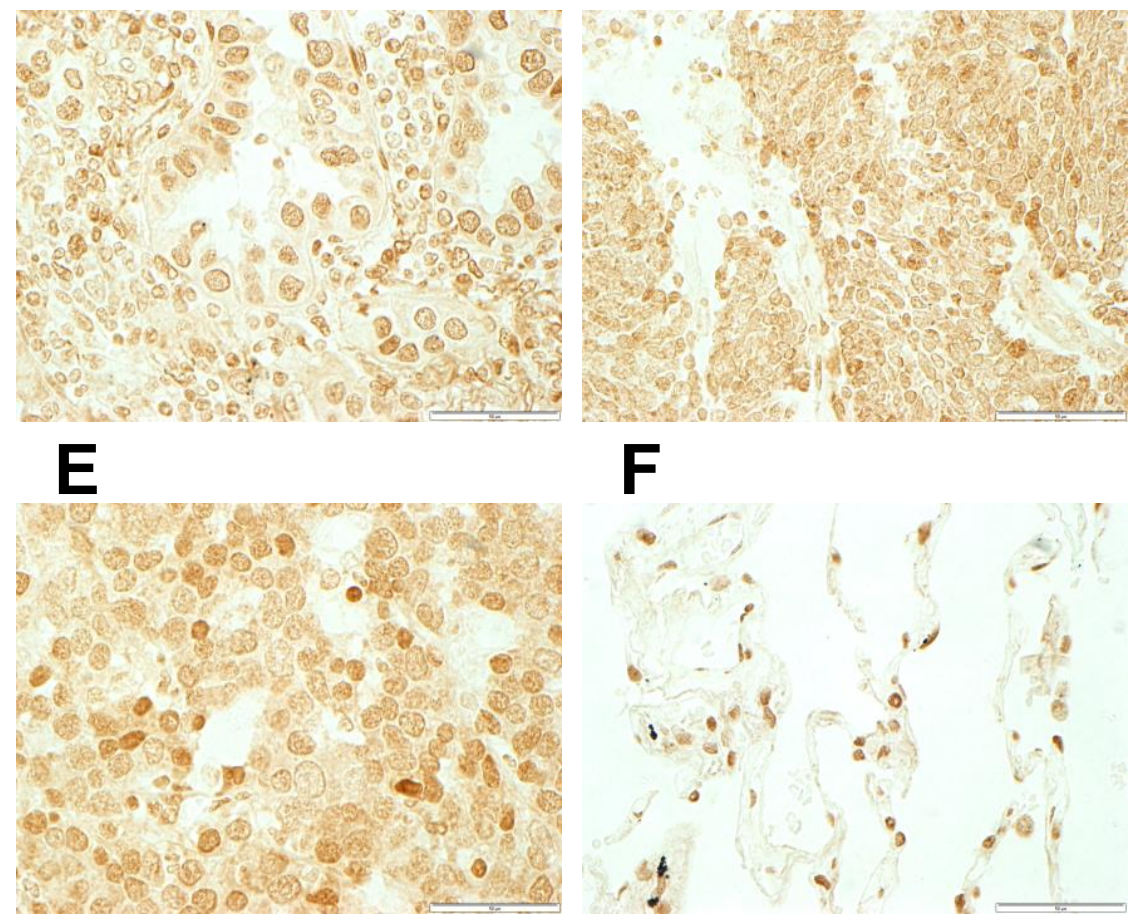

Fig. 3 
Fig. 4

\section{Up-regulated Genes}

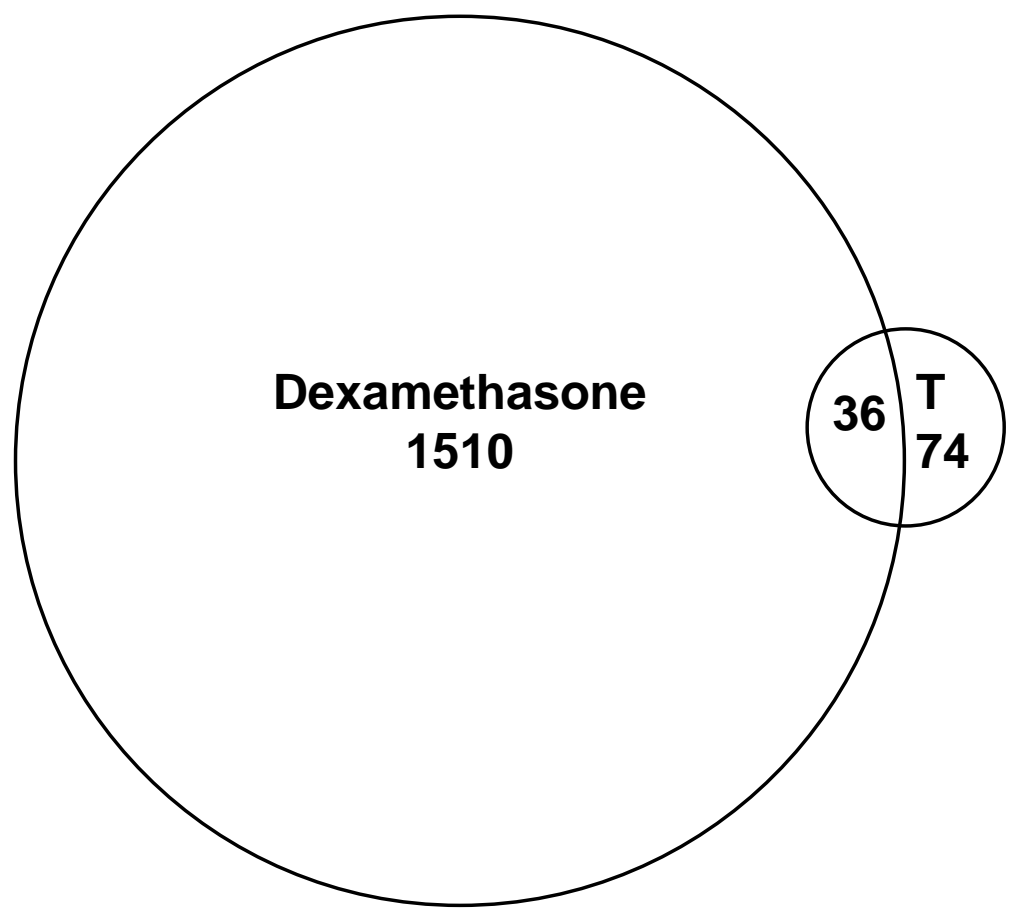

Down-regulated Genes

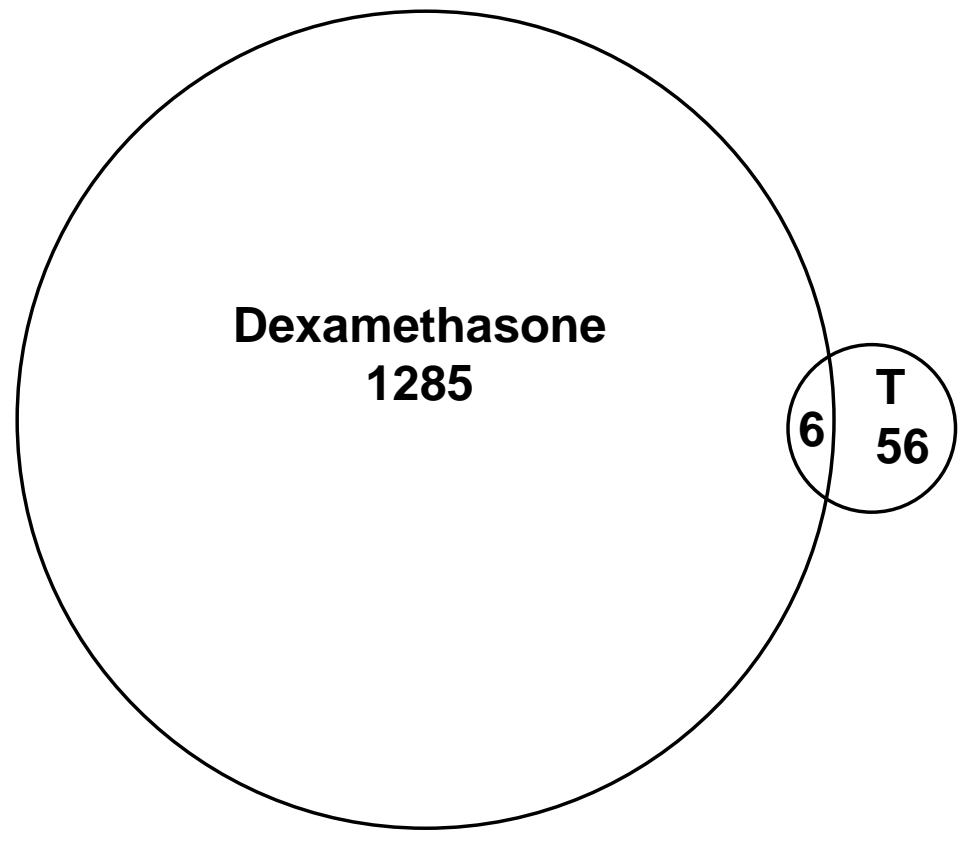

Fig. 4 


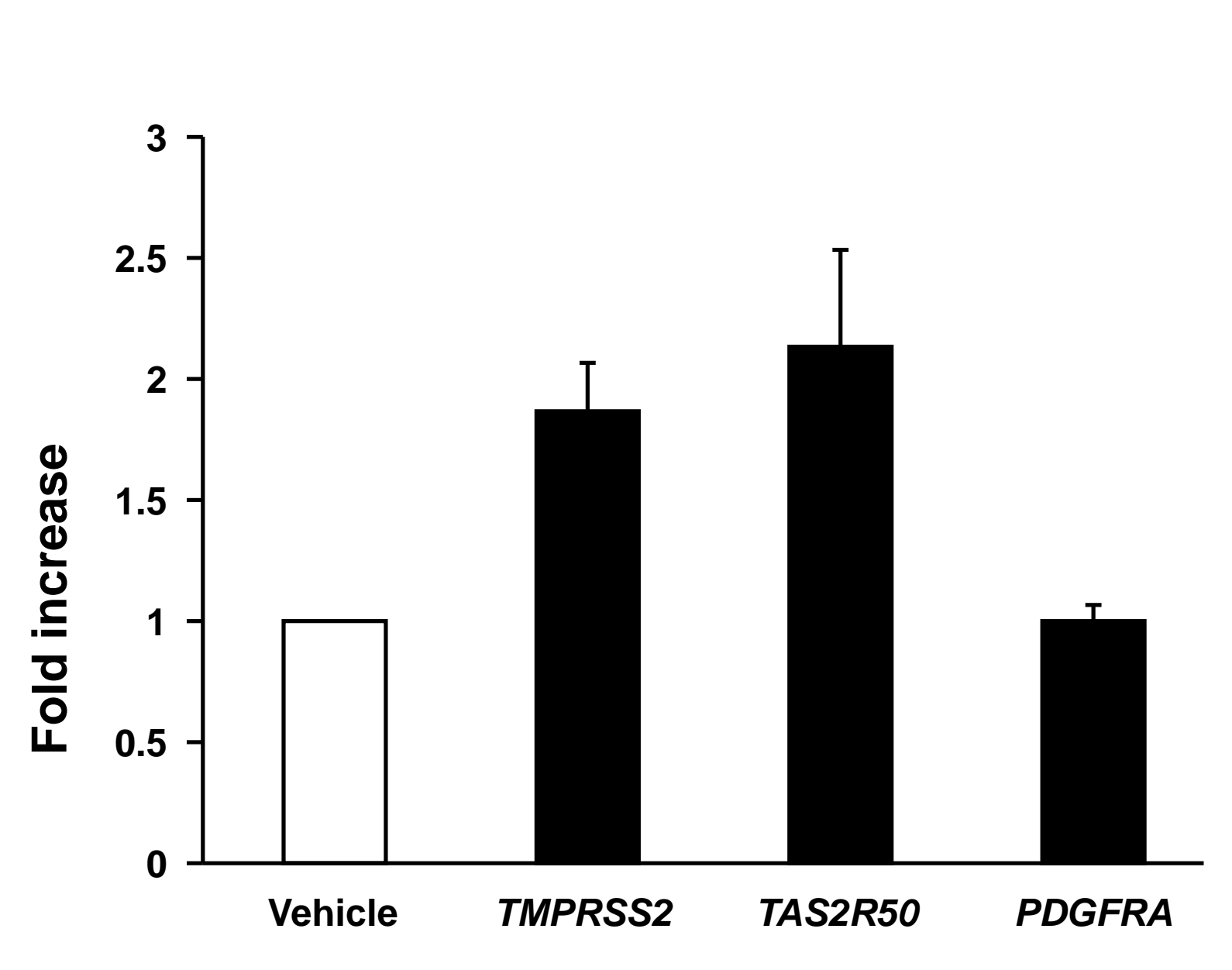

Fig. 5

Fig. 5

Fig. 5

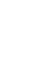

F. 5

.

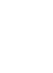

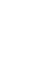

